\title{
European Sectoral Qualifications Framework for Military Officer Profession from the Perspective of the Czech Republic
}

\section{Evropský sektorový kvalifikační rámec důstojníka ozbrojených sil z perspektivy České republiky}

\section{Richard Saibert}

Abstract: The article deals with the issue of application of the European Sectoral Qualifications Framework for Military Officer Profession. Paper brings the main results of levelling the Senior Officer Course to the European Core Curriculum for Military Officers (MILOF-CORE). It was found out that 18 out of 35 learning outcomes of the Senior Officer Course were found to considerable degree relevant to the MILOF-CORE, the rest contain a various degree of national specifics. Lessons learned gained from the levelling were employed in a recent revision of study programs of the career courses organized by the Center for Security and Military Strategic Studies of the University of Defence.

Abstrakt: CClánek se zabývá problematikou aplikace Evropského sektorového kvalifikačního rámce důstojníka ozbrojených sil. Příspěvek přináší hlavní výsledky procesu přiřazení českého kurzu vyšších důstojníků k Evropskému kurikulu pro důstojníky ozbrojených sil (MILOF-CORE). Bylo zjištěno, že 18 z 35 porovnávaných výsledků učení vzdělávacího programu pro vyšší důstojníky bylo shledáno do značné míry relevantní s MILOF-CORE, zbytek výstupů z učení zahrnuje různou míru, především národních specifik. Zkušenosti a poznatky získané z procesu přiřazení byly využity při nedávné revizi studijních programů kariérových kurzů organizovaných Centrem bezpečnostních a vojenskostrategických studií Univerzity obrany.

Keywords: European Sectoral Qualifications Framework for Military Officer Profession; Senior Officer Course; National Military Qualifications.

Klíčová slova: Evropský sektorový kvalifikační rámec důstojníka ozbrojených sil; kurz pro vyšší důstojníky; národní vojenské kvalifikace. 


\section{INTRODUCTION}

Competency based approach to military personnel education represents one of the long-term goals solved by the Center for Security and Military Strategic Studies (CSMSS) within the Research Project - ARMED CONFLICT. This path has been followed for the purpose of officers' career education. One of the research objectives is to develop a set of competency requirements for officers at the middle and senior level of command and control. European Sectoral Qualifications Framework for the Military Officer Profession (SQF-MILOF) represents a solid structure to be utilized for the purposes of formulating required officer's competencies as well as supporting learning outcomes using specific descriptors such as the knowledge, skills and autonomy \& responsibility (competency). Similar approach was applied in published article dealing with an identification of competencies for commanders in leading units in military operations where both the SQF-MILOF and the European Union (EU) Commission Database for the Armed Forces had been proven as the most relevant frameworks providing military officer's competencies ${ }^{1}$.

Czech Republic has participated in the SQF-MILOF working group since the very beginning (since 2018). Czech representatives including the author of this paper contributed mainly to the definition and description of learning outcomes for individual levels of an officer's career. The development of the SQF-MILOF has reached its completion. Paper discusses results of recent process of validation where the EU Member States were invited to confirm the utility and completeness of the SQF-MILOF. As a part of this informal procedure some member countries, including the Czech Republic, verified to what extent the learning outcomes described by the European Core Curriculum for Military Officers (MILOF-CORE) can be used for their own national military qualifications (NMQ). Such verification is based on the process of levelling (assignment).

Levelling of the Czech NMQ was accomplished in the internal study comparing the MILOF-CORE with the study program for senior officers ${ }^{2}$. The study identifies areas of conformity between the learning outcomes defined in the study program and the descriptors formulated in the MILOF-CORE. The aim of this article is to present and discuss the main findings of that study.

1 ŠTĚPÁNEK, Přemysl and Richard SAIBERT. Officer's Competencies. Vojenské rozhledy. 2020, 29 (1), 051-070. ISSN 1210-3292 (print), 2336-2995 (online). Available at: www.vojenskerozhledy. $C Z$

2 SAIBERT, Richard. Možnosti aplikace Evropského sektorového kvalifikačního rámce důstojníka ozbrojených sil $v$ podmínkách kariérového vzdělávání (Possibilities of an application of the European Sectoral Qualifications Framework for Military Officer Profession to the conditions of career education) [study]. University of Defence, Brno: 2021, 14 p. 


\section{EUROPEAN SECTORAL QUALIFICATIONS FRAMEWORK FOR MILITARY OFFICER PROFESSION}

Defence cooperation is an integral part of the EU agenda. In 2016, the European Parliament called on the European Council to take practical steps to harmonize and standardize the European Armed Forces. The overarching goal was to promote cooperation between members of armed forces within the new European Defence Union. From this point of view, the concept of interoperability of armed forces represents the highest degree of standardization that can be achieved among the EU Member States.

Although training of military personnel is fully the responsibility of member states themselves, a high level of interoperability can only be achieved through a transparent and critical approach to the development of military training, training programs and systems $^{3}$. SQF-MILOF is a tool designed to promote mutual cooperation which offers the EU members a platform for an exchange of views on the required level of capabilities and skills of military personnel and the related issue of their training. Sectoral Qualifications Framework needs to be understood in the broader context of an EU-wide military qualifications architecture. The purpose of the SQF-MILOF is to encourage national training and education providers to design NMQ in the spirit of the principles of European quality assurance as well as to offer a tool for comparison military qualifications obtained in one member state with similar qualifications awarded by another member state ${ }^{4}$.

SQF-MILOF provides a comprehensive framework defining competencies for all categories of military personnel (officers) across all types of forces and services and at all levels of command and control. This framework therefore includes learning areas from the basic to the most advanced level of military education. Requirements for competencies that an officer should demonstrate are identified on the basis of the factors, such as dealing with change, time horizon for operations planning, application of management and leadership etc. A detailed list of all aspects is illustrated in Figure 1 - Basic characteristics of an officer's career.

3 PAILE, Sylvain, 2014. European Education and Training for Young Officers: The European Initiative for the Exchange of Young Officers Inspired by ERASMUS. Brussels: European Security and Defence College (ESDC). ISBN 978-92-95201-01-9.

4 Sectoral Qualifications Framework for the Military Officer Profession- SQF-MILOF, European Security and Defence College, Brussels, ESDC/2020/234, 2020, ESDC Secretariat. 


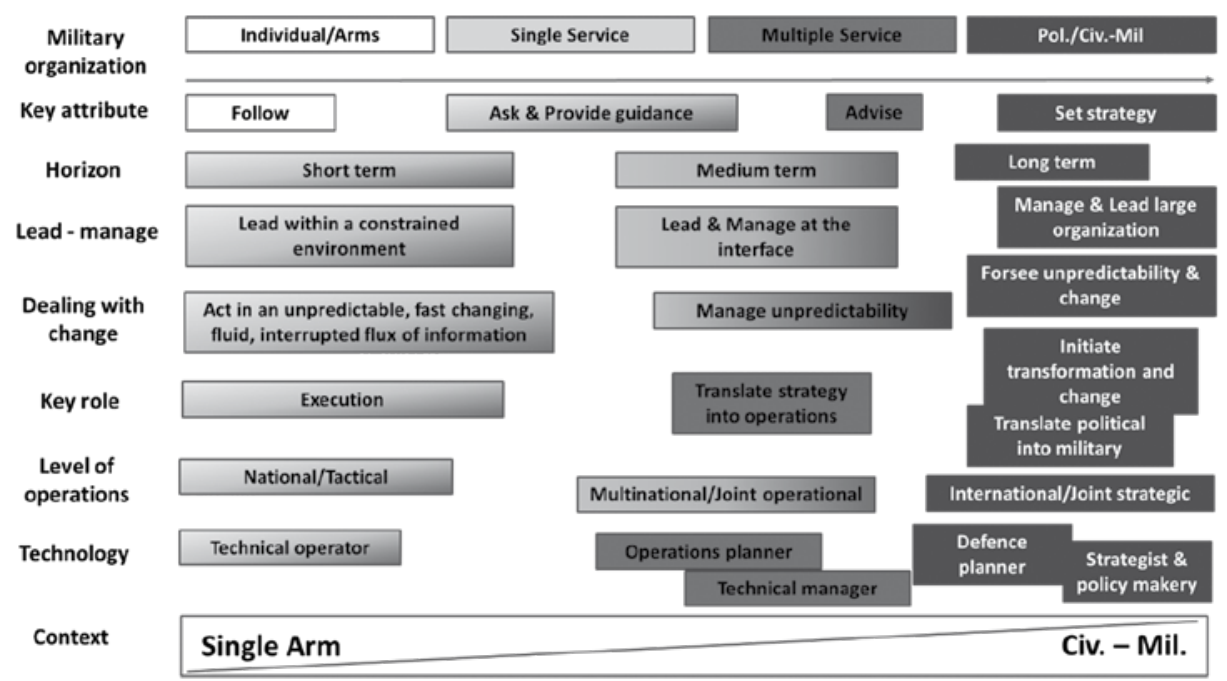

Picture 1: Basic characteristic of officer's career

Source: Sectoral Qualifications Framework for the Military Officer Profession- SQF-MILOF, European Security and Defence College, Brussels, ESDC/2020/234, 2020, ESDC Secretariat.

Sectoral Qualifications Framework is structured into certain educational levels (1-4) based on an officer's career stage, respectively achieved military rank, informally assigned to the European Qualifications Framework (EQF 5-8). For each educational level, the SQF-MILOF comprises descriptors in the form of knowledge, skills and autonomy \& responsibility (SQF-MILOF Descriptors) reflecting complexity and difficulty of required learning outcomes according to the EQF.

MILOF-CORE then categorizes competencies into 8 areas (core) ${ }^{5}$ in which it is assumed that an officer can work within his military career for each predefined learning area. Additional determining aspect is the military focus from the perspective of military organizational context, i.e. level of military structure and levels of operations (MILOF-CORE Focus) 6 . Some learning areas are universal to all levels of military organization and therefore they are called common. MILOF-CORE shown in Table 1 represents a matrix which verifies how each competency (listed in a box such as SQF-MILOF Descriptors) is supported by a tangible learning outcome.

5 Those roles are: 1) Military Service Member; 2) Military Technician; 3) Leader and Decision Maker; 4) Combat-ready Model; 5) Communicator; 6) Learner and Teacher/Coach; 7) Critical Thinker and Researcher; 8) International Security/Diplomacy Actor.

6 Sectoral Qualifications Framework for the Military Officer Profession - SQF MILOF: Volume 02, 2021. Luxembourg: European Security and Defence College. ISBN 978-92-9463-011-7 
Table 1: MILOF-CORE Structure - example

\begin{tabular}{|c|c|c|c|c|c|}
\hline \multicolumn{6}{|c|}{ Competence Area (core): 1) Military service member } \\
\hline \multirow{2}{*}{$\begin{array}{l}\text { MILOF-CORE } \\
\text { Focus }\end{array}$} & \multicolumn{5}{|c|}{ SQF-MILOF Level } \\
\hline & \multicolumn{2}{|c|}{$\begin{array}{c}\text { Level } 1 \\
\text { EQF } 5\end{array}$} & $\begin{array}{c}\text { Level } 2 \\
\text { EQF } 6\end{array}$ & $\begin{array}{l}\text { Level } 3 \\
\text { EQF } 7\end{array}$ & $\begin{array}{l}\text { Level } 4 \\
\text { EQF } 8\end{array}$ \\
\hline \multicolumn{6}{|c|}{ Learning Area: Employment of Forces - Full Spectrum Operations } \\
\hline \multirow{3}{*}{ 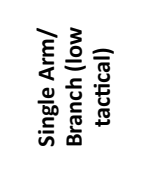 } & \multirow{3}{*}{$\begin{array}{l}\text { SQF-MILOF } \\
\text { Descriptors }\end{array}$} & Knowledge & \multirow{3}{*}{$\begin{array}{l}\text { Explain the principles } \\
\text { of employing single } \\
\text { arm/ branch subunits } \\
\text { at the tactical level } \\
\text { in accordance with } \\
\text { national doctrine... }\end{array}$} & \multirow{3}{*}{$\begin{array}{l}\text { Critically evaluate and } \\
\text { prioritise the tasks and } \\
\text { means assigned by the } \\
\text { higher echelon taking } \\
\text { into account the role } \\
\text { of other branches... }\end{array}$} & \multirow[b]{3}{*}{$\mathrm{n} / \mathrm{a}$} \\
\hline & & Skills & & & \\
\hline & & $\begin{array}{l}\text { Autonomy \& } \\
\text { Responsibility }\end{array}$ & & & \\
\hline 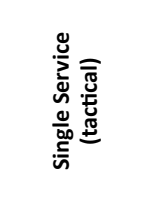 & \multicolumn{2}{|c|}{$\begin{array}{l}\text { Discuss the organisation } \\
\text { and basic principles of } \\
\text { employing forces at } \\
\text { the service level... }\end{array}$} & $\begin{array}{l}\text { Explain the principles } \\
\text { of employing } \\
\text { combined arms forces } \\
\text { at the tactical level } \\
\text { in accordance with } \\
\text { doctrine, across the full } \\
\text { spectrum of operations... }\end{array}$ & $\begin{array}{l}\text { Explore the } \\
\text { requirements/ conditions } \\
\text { of integrating the } \\
\text { effects of fire, influence } \\
\text { and manoeuvre in } \\
\text { joint operations... }\end{array}$ & $\mathrm{n} / \mathrm{a}$ \\
\hline 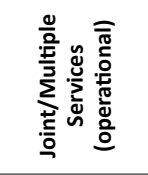 & \multicolumn{2}{|c|}{$\begin{array}{l}\text { Describe the possibilities } \\
\text { of the different services, } \\
\text { equally the composition } \\
\text { and force enablers } \\
\text { and multipliersl... }\end{array}$} & $\begin{array}{l}\text { Explain the principles } \\
\text { of employing units } \\
\text { and formations at the } \\
\text { operational level in } \\
\text { a joint multinational } \\
\text { context... }\end{array}$ & $\begin{array}{l}\text { Critically assess the } \\
\text { service-specific forces } \\
\text { capabilities, organization } \\
\text { and specific activities / } \\
\text { allocate resources... }\end{array}$ & $\mathrm{n} / \mathrm{a}$ \\
\hline 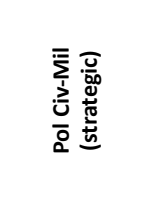 & \multicolumn{2}{|c|}{$\begin{array}{l}\text { Explain the key elements } \\
\text { of relevant multinational } \\
\text { doctrines (UN, EU, NATO) } \\
\text { for joint operations... }\end{array}$} & $\begin{array}{l}\text { Analyse the strategic } \\
\text { employment of armed } \\
\text { forces as part of } \\
\text { an integrated crisis } \\
\text { response architecture } \\
\text { at national and } \\
\text { multinational levels... }\end{array}$ & $\begin{array}{l}\text { Integrate the context/ } \\
\text { conditions and } \\
\text { constraints of employing } \\
\text { military organisations/ } \\
\text { formations at the } \\
\text { strategic level... }\end{array}$ & $\begin{array}{l}\text { Critically evaluate the } \\
\text { correlation between } \\
\text { the force structure, } \\
\text { military strategy and } \\
\text { political objectives... }\end{array}$ \\
\hline \multicolumn{6}{|c|}{ Learning Area: National and International Law } \\
\hline ¿̊ & \multicolumn{2}{|c|}{$\begin{array}{l}\text { Outline the range } \\
\text { of national, EU and } \\
\text { international law and } \\
\text { military regulations } \\
\text { with relevance to the } \\
\text { military domain... }\end{array}$} & $\begin{array}{l}\text { Define and interpret } \\
\text { the range of national, } \\
\text { EU and international } \\
\text { law, military regulations } \\
\text { with relevance to the } \\
\text { military domain... }\end{array}$ & $\begin{array}{l}\text { Critically evaluate } \\
\text { the impact of the } \\
\text { legal framework } \\
\text { (international and } \\
\text { national law, ROE's,...) } \\
\text { on the effectiveness of } \\
\text { military operations... }\end{array}$ & $\begin{array}{l}\text { Appraise situations } \\
\text { that require changes } \\
\text { and new provisions for } \\
\text { relevant national law and } \\
\text { regulations with regard } \\
\text { to military profession... }\end{array}$ \\
\hline
\end{tabular}

Source: Based on "Sectoral Qualifications Framework for the Military Officer Profession- SQF-MILOF," European Security and Defence College, Brussels, ESDC/2020/234, 2020, ESDC Secretariat.

\section{METHODOLOGY OF LEVELLING THE SENIOR OFFICER COURSE TO THE SQF-MILOF}

As was mentioned in the introductory chapter the Czech Republic was one of countries which verified to what extent the SQF-MILOF learning outcomes are usable for its NMQ through the process of levelling. As a part of the following analysis there were compared the Senior Officer Course $(\mathrm{SOC}$ ) as a lifelong learning program provided by 
$\mathrm{CSMSS}^{7}{ }^{8}$ with the MILOF-CORE. The main objective of this investigation was to determine whether Czech national study program can be assigned (levelled) to the SQF-MILOF in terms of its content. Based on the career course curriculum 35 learning outcomes from the area of the knowledge and skills were identified. Those outcomes especially from the area of knowledge were partially reformulated using verb descriptors to allow either measurability of acquired knowledge or mutual comparability with the MILOF-CORE.

The following learning outcomes of the SOC were identified:

1. Informed of the theory of war, military strategy and operational art with the application of knowledge and experience from current armed conflicts and operations.

2. Skilled in operational art and tactics with an emphasis on understanding the context and experience of armed conflict and on mastering the main principles of military art.

3. Familiar with current security situation in crisis regions and characteristics of selected armed conflicts.

4. Capable of analysis of the operating environment and analysis of the area of operation.

5. Familiar with the principles of planning and conducting combat and non-combat operations by a task force based on a mechanized brigade, division and the equivalent of an air forces.

6. Capable of creative application of the principles of preparation and use of multiple branches of armed forces and combat support and combat service support elements at the operational and tactical level, with a focus on the brigade task force.

7. Master the military decision-making process (MDMP) and staff activities in combat planning at the tactical and operational level.

8. Familiar with the MDMP at operational level.

9. Knowledge of the role of key elements of the international security architecture (UN, NATO, EU) and their current activities with an emphasis on the involvement of the Armed Forces of the Czech Republic (CAF).

10. Capable to formulate the mission, vision and goals of the organizational unit.

11. Apply leadership styles in change management in the organization.

12. Able to understand the principles of organizational leadership, leadership styles, moral theory, theory of interpersonal behaviour and actions in change management within the organization and conflict resolution.

13. Conversant in organizational culture and its change, application of leadership styles and ways of personal development of subordinates, the principles of

7 Přípravná studie programu celoživotního vzdělávání, Kurz pro vyšší důstojníky (Preparatory study of the lifelong learning program, Senior Officer Course), CSMSS University of Defence, Brno 2020.

8 Studijní dokumentace programu celoživotního vzdělávání, Kurz pro vyšší důstojníky (Study curriculum of the lifelong learning program, Senior Officer Course), CSMSS University of Defence, Brno 2020. 
team building, including communication techniques used especially in negotiating and resolving interpersonal conflicts.

14. Skilled in identification, evaluation and designating risk management methods.

15. Informed of principles of capability development of armed forces from the perspective of view of life cycle.

16. Competent in using of analytical methods, modelling and simulation and experimentation to support the MDMP at the operational and tactical level, risk management.

17. Skilled in presenting and defending own ideas, opinions and recommendations.

18. Conversant in current social, political, and military events in the national and international environment and their implications for the preparation, planning and conducting the operations in the territory of the Czech Republic and beyond.

19. Aware of development of the security environment and its consequences for the CAF.

20. Familiar with principles of management, preparation and use of the CAF.

21. Familiar with the use of the CAF (tasks forces based on mechanized brigade, mechanized division and the equivalent of air forces) for the defence of the Czech Republic in multinational operations within the component of the branches of armed forces (land component command, air component command).

22. Informed of the political, legal and security system of the Czech Republic and its links to the CAF.

23. Conversant in the basic starting points and directions of the Czech Republic's defence policy.

24. Informed of the basics of defence planning.

25. Skilled in methods of building and leading teams and developing social competencies of members of the CAF.

26. Participate to crisis management planning, operations planning, mobilization planning and peacetime planning.

27. Conversant with training and use of various branches of forces and services in supporting and securing military units in combat/ operation.

28. Skilled in organization of coordination during the preparation and conduct of operations.

29. Aware of force protection in operations.

30. Familiar with doctrinal activities and the Lessons Learned.

31. Familiar with combat ethos and skilled in its application in practice.

32. Informed of the foundations of international war law.

33. Able to apply methods of alternative analysis to support the MDMP.

34. Competent in leading teams to achieve set goals and improve the organization's activities.

35. Capable to apply moral standards to subordinate units and staffs.

The basic criterion for the levelling was the occurrence of keywords / terms contained in a specific SOC learning outcome on the basis of which a relationship with the MILOF-CORE was sought. In a case of a match between particular learning outcomes, the result was supplemented by competence area (core), learning area, further SQF-MILOF educational level and the level of military organizational architecture (MILOF-CORE Focus). 
The results of the mutual comparison between SOC learning outcomes and the MILOF-CORE are shown in Table 1. Paper presents only those examples, where note indicates a specificity or restriction in a given learning outcomes. The whole comparison (levelling) is worked out in the internal study ${ }^{9}$. Serial numbers are the same as the number of the above listed SOC identified learning outcomes.

Table 2: Levelling SOC learning outcomes to MILOF-CORE

\begin{tabular}{|c|c|c|c|c|c|}
\hline \multirow{3}{*}{ Nr. } & \multirow{3}{*}{$\begin{array}{c}\text { SOC } \\
\text { Learning Outcomes }\end{array}$} & $\begin{array}{c}\text { MILOF-CORE } \\
\text { Learning Outcomes }\end{array}$ & \multirow{3}{*}{ 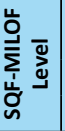 } & \multirow{3}{*}{$\begin{array}{l}\text { MILOF-CORE } \\
\text { Focus }\end{array}$} & \multirow{3}{*}{ Note } \\
\hline & & Competence Area (core) & & & \\
\hline & & Learning Area & & & \\
\hline \multirow[t]{3}{*}{4} & \multirow[t]{3}{*}{$\begin{array}{l}\text { Capable of analysis of the } \\
\text { operating environment and } \\
\text { analysis of the area of operation }\end{array}$} & $\begin{array}{l}\text { Selectively apply appropriate tools } \\
\text { and techniques to diverse situations } \\
\text { to optimise military efficiency in } \\
\text { the operational environment }\end{array}$ & \multirow[t]{3}{*}{3} & \multirow[t]{3}{*}{ Common } & \multirow{3}{*}{$\begin{array}{l}\text { SQF-MILOF } \\
\text { focuses } \\
\text { only on the } \\
\text { analysis of } \\
\text { the operating } \\
\text { environment }\end{array}$} \\
\hline & & Leader and Decision-Maker & & & \\
\hline & & Change management & & & \\
\hline \multirow[t]{6}{*}{5} & \multirow[t]{6}{*}{$\begin{array}{l}\text { Familiar with the principles of } \\
\text { planning and conducting combat } \\
\text { and non-combat operations } \\
\text { by a task force based on a } \\
\text { mechanized brigade, division and } \\
\text { the equivalent of the Air Forces }\end{array}$} & $\begin{array}{l}\text { Describe the operations planning } \\
\text { process at the operational level } \\
\text { for a potential crisis situation in } \\
\text { full spectrum of operations at } \\
\text { national/ multinational levels }\end{array}$ & \multirow[t]{3}{*}{1} & \multirow[t]{3}{*}{$\begin{array}{c}\text { Joint/ } \\
\text { Multiple } \\
\text { Services } \\
\text { (operational) }\end{array}$} & \multirow[t]{3}{*}{$\begin{array}{l}\text { SQF-MILOF } \\
\text { is aimed at } \\
\text { operations } \\
\text { planning only }\end{array}$} \\
\hline & & Military service member & & & \\
\hline & & Operations planning & & & \\
\hline & & $\begin{array}{l}\text { Critically evaluate the capabilities of } \\
\text { Command, control, communications, } \\
\text { computers, intelligence, surveillance } \\
\text { and reconnaissance and cyber } \\
\text { defence systems, integrate their } \\
\text { requirements in the planning } \\
\text { and conduct of full spectrum } \\
\text { operations at the tactical level }\end{array}$ & \multirow[t]{3}{*}{3} & \multirow[t]{3}{*}{$\begin{array}{l}\text { Single Service } \\
\text { (tactical) }\end{array}$} & \multirow[t]{3}{*}{$\begin{array}{l}\text { SQF-MILOF } \\
\text { is focused } \\
\text { on the } \\
\text { integration } \\
\text { of C4ISTAR } \\
\text { and Cyber } \\
\text { into the } \\
\text { planning and } \\
\text { management } \\
\text { of operations }\end{array}$} \\
\hline & & Military Technician & & & \\
\hline & & $\begin{array}{l}\text { Command, control, communications, } \\
\text { computers, intelligence, } \\
\text { surveillance and reconnaissance } \\
\text { systems \& Cyber Defence }\end{array}$ & & & \\
\hline \multirow[t]{3}{*}{6} & \multirow[t]{3}{*}{$\begin{array}{l}\text { Capable of creative application of } \\
\text { the principles of preparation and use } \\
\text { of multiple branches of armed forces } \\
\text { and combat support and combat } \\
\text { service support elements at the } \\
\text { operational and tactical level, with } \\
\text { a focus on the brigade task force }\end{array}$} & $\begin{array}{l}\text { Explain the combat service } \\
\text { support capabilities of units and } \\
\text { formations specific to the service } \\
\text { during full spectrum operations } \\
\text { and take the logistics requirements } \\
\text { into account during planning } \\
\text { of full spectrum operations }\end{array}$ & \multirow[t]{3}{*}{2} & \multirow[t]{3}{*}{$\begin{array}{l}\text { Single Service } \\
\text { (tactical) }\end{array}$} & \multirow[t]{3}{*}{$\begin{array}{l}\text { SQF-MILOF } \\
\text { is focused } \\
\text { only on a } \\
\text { combat } \\
\text { service } \\
\text { support } \\
\text { capability }\end{array}$} \\
\hline & & Military Technician & & & \\
\hline & & Sustaining the Force & & & \\
\hline
\end{tabular}

9 SAIBERT, Richard. Možnosti aplikace Evropského sektorového kvalifikačního rámce důstojníka ozbrojených sil v podmínkách kariérového vzdělávání (Possibilities of an application of the European Sectoral Qualifications Framework for Military Officer Profession to the conditions of career education) [study]. University of Defence, Brno: 2021, 14 p. 


\begin{tabular}{|c|c|c|c|c|c|}
\hline \multirow{3}{*}{ Nr. } & \multirow{3}{*}{$\begin{array}{c}\text { SOC } \\
\text { Learning Outcomes }\end{array}$} & $\begin{array}{c}\text { MILOF-CORE } \\
\text { Learning Outcomes }\end{array}$ & \multirow{3}{*}{ 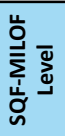 } & \multirow{3}{*}{$\begin{array}{l}\text { MILOF-CORE } \\
\text { Focus }\end{array}$} & \multirow{3}{*}{ Note } \\
\hline & & Competence Area (core) & & & \\
\hline & & Learning Area & & & \\
\hline \multirow[t]{3}{*}{9} & \multirow{3}{*}{$\begin{array}{l}\text { Knowledge of the role of key } \\
\text { elements of the international security } \\
\text { architecture (UN, NATO, EU) and their } \\
\text { current activities with an emphasis } \\
\text { on the involvement of the CAF }\end{array}$} & $\begin{array}{l}\text { Analyse the strategic employment of } \\
\text { armed forces as part of an integrated } \\
\text { crisis response architecture at } \\
\text { national and multinational levels }\end{array}$ & \multirow[t]{3}{*}{2} & \multirow[t]{3}{*}{$\begin{array}{l}\text { Pol Civ-Mil } \\
\text { (strategic) }\end{array}$} & \multirow{3}{*}{$\begin{array}{l}\text { SOC is } \\
\text { focused } \\
\text { mainly on } \\
\text { implications } \\
\text { for the CAF }\end{array}$} \\
\hline & & Military service member & & & \\
\hline & & $\begin{array}{l}\text { Employment of forces- Full } \\
\text { Spectrum Operations }\end{array}$ & & & \\
\hline \multirow[t]{3}{*}{11} & \multirow[t]{3}{*}{$\begin{array}{l}\text { Apply leadership styles in change } \\
\text { management in the organization }\end{array}$} & $\begin{array}{l}\text { Explain the principles of change } \\
\text { management and the effects on } \\
\text { the military science/domain }\end{array}$ & \multirow[t]{3}{*}{2} & \multirow[t]{3}{*}{ Common } & \multirow{3}{*}{$\begin{array}{l}\text { SQF-MILOF } \\
\text { is focused } \\
\text { partly only on } \\
\text { the principles } \\
\text { of change } \\
\text { management }\end{array}$} \\
\hline & & Leader and Decision-Maker & & & \\
\hline & & Change management & & & \\
\hline \multirow[t]{3}{*}{15} & \multirow[t]{3}{*}{$\begin{array}{l}\text { Informed of the principles } \\
\text { of capability development } \\
\text { of armed forces from the } \\
\text { perspective of life cycle }\end{array}$} & $\begin{array}{l}\text { Describe the lifecycle and } \\
\text { development requirements of } \\
\text { weapons/operating systems } \\
\text { specific to the service }\end{array}$ & \multirow[t]{3}{*}{2} & \multirow[t]{3}{*}{$\begin{array}{l}\text { Single Service } \\
\text { (tactical) }\end{array}$} & \multirow{3}{*}{$\begin{array}{l}\text { SOC is } \\
\text { focused on } \\
\text { building the } \\
\text { capabilities } \\
\text { of the CAF in } \\
\text { accordance } \\
\text { with the } \\
\text { NATO } \\
\text { defence } \\
\text { planning }\end{array}$} \\
\hline & & Military Technician & & & \\
\hline & & $\begin{array}{l}\text { Employment of weapon/ } \\
\text { operating platform/ systems) }\end{array}$ & & & \\
\hline \multirow[t]{3}{*}{ ř16 } & \multirow[t]{3}{*}{$\begin{array}{l}\text { Competent in using of analytical } \\
\text { methods, modelling and simulation } \\
\text { and experimentation to support } \\
\text { MDMP process at the operational } \\
\text { and tactical level; risk management }\end{array}$} & $\begin{array}{l}\text { Explain and implement the research } \\
\text { techniques, sources, resources and } \\
\text { data processing methods to solve } \\
\text { issues in the military domain/science. }\end{array}$ & \multirow[t]{3}{*}{2} & \multirow[t]{3}{*}{ Common } & \multirow{3}{*}{$\begin{array}{l}\text { SOC is } \\
\text { focused } \\
\text { especially } \\
\text { on the use } \\
\text { of methods } \\
\text { supporting } \\
\text { MDMP }\end{array}$} \\
\hline & & Critical Thinker and Researcher & & & \\
\hline & & $\begin{array}{l}\text { Research, analysis, data } \\
\text { processing methods }\end{array}$ & & & \\
\hline \multirow[t]{3}{*}{18} & \multirow[t]{3}{*}{$\begin{array}{l}\text { Conversant in current social, political, } \\
\text { and military events in the national } \\
\text { and international environment } \\
\text { and their implications for the } \\
\text { preparation, planning and conducting } \\
\text { the operations in the territory of } \\
\text { the Czech Republic and beyond }\end{array}$} & $\begin{array}{l}\text { Critically evaluate the distinct and } \\
\text { overlapping roles between civilian } \\
\text { and military institutions as part of } \\
\text { the security sector of a nation, and } \\
\text { at supranational level, under political } \\
\text { supervision and civilian oversight }\end{array}$ & \multirow[t]{3}{*}{3} & \multirow[t]{3}{*}{ Common } & \multirow{3}{*}{$\begin{array}{l}\text { SOC is } \\
\text { focused on } \\
\text { the context of } \\
\text { implications } \\
\text { for the } \\
\text { preparation } \\
\text { of forces and } \\
\text { resources for } \\
\text { operations }\end{array}$} \\
\hline & & Military service member, & & & \\
\hline & & Civilian-Military Relations & & & \\
\hline
\end{tabular}

During the levelling 18 SOC learning outcomes were assigned to the MILOF-CORE. In all cases, however, it can be stated that there are more important or less substantial differences in the description of a particular learning outcome as it is given by detailed explanation in the notes. In a case of SOC learning outcomes nr. 19 - 35, no agreement with the outcomes in the SQF-MILOF was found. This is particularly striking for the following learning outcomes:

19. Aware of development of the security environment and its consequences for the CAF.

20. Familiar with principles of management, preparation and use of the CAF.

21. Familiar with the use of the CAF (tasks forces based on mechanized brigade, mechanized division and the equivalent of air forces) for the defence of the Czech Republic in multinational operations within the component of the branches of armed forces (land component command, air component command). 
22. Informed of the political, legal and security system of the Czech Republic and its links to the CAF.

23. Conversant in the basic starting points and directions of the Czech Republic's defence policy.

24. Informed of the basics of defence planning (within the Czech Ministry of Defence environment/CAF).

25. Skilled in methods of building and leading teams and developing social competencies of members of the CAF (within the Czech Ministry of Defence environment/CAF).

26. Participate to crisis management planning, operations planning, mobilization planning and peacetime planning (within the Czech Ministry of Defence environment; based on NATO rules and guidelines).

30. Familiar with doctrinal activities and the Lessons Learned (based on NATO rules and guidelines).

Note: Serial numbers are the same as the numbers of the above listed SOC identified learning outcomes.

\section{LEVELLING FROM THE PERSPECTIVE OF OTHER EU MEMBER STATES}

In the course of levelling national military qualifications to the SQF-MILOF and defining military focus, other training providers from six EU Member States (AT, BG, HU, IT, $\mathrm{LT}$ and RO) accomplished this process ${ }^{10}$. Those educational programs chosen for levelling were formal university education such as Master's degree programs or different level officer's career courses. The following study programs including that from the Czech Republic were chosen for mutual comparison:

1. Bulgaria, Nikola Vaptsarov Naval Academy

- Naval Tactical Level Officer

2. Romania, National Defence University, Crisis Management and Multinational Operations Department

- $\quad$ Brigade Staff Officer Course

3. Italy, Centre for Defence Higher Studies, Joint Services Staff College

- $\quad$ Advanced Joint Staff Course

4. Austria, Theresian Military Academy, Institute for Basic Officer Education

- Vocational courses on general Infantry training at Platoon level

5. Czech Republic, University of Defence, Center for Security and Military Strategic Studies

- $\quad$ Senior Officer Course

10 Levelling national military qualifications to SQF-MILOF and defining their military focus - Informal Validation Outcomes, European Security and Defence College, Brussels, ESDC/2021/051, 2021, ESDC Secretariat. 
6. Hungary, Ludovika - University of Public Service, Faculty of Military Science and Officer Training

- Joint Operational Staff Course

7. Lithuania, General Jonas Žemaitis Military Academy

- $\quad$ Master of Defence Studies

Majority of education and training providers found the process quite easy to complete. Most of them found that all the MILOF-CORE outcomes are necessary and match very well to the national learning outcomes. Nonetheless, there was expressed a concern that there might be a confusion because some providers used for basic officers' education the framework developed under the Implementation Group ${ }^{\mathbf{1 1}}$ (leading the Military Erasmus programme), which overlaps with the SQF-MILOF. There was also an indication that in the case of courses with generic learning outcomes, the determination of the key learning outcomes depends on national/concrete providers preferences. Therefore, the levelling of similar courses of various Member States may be different, depending on each training provider's perception or appreciation of key learning outcomes. Comparison of the outcomes of levelling is shown in Picture 2.

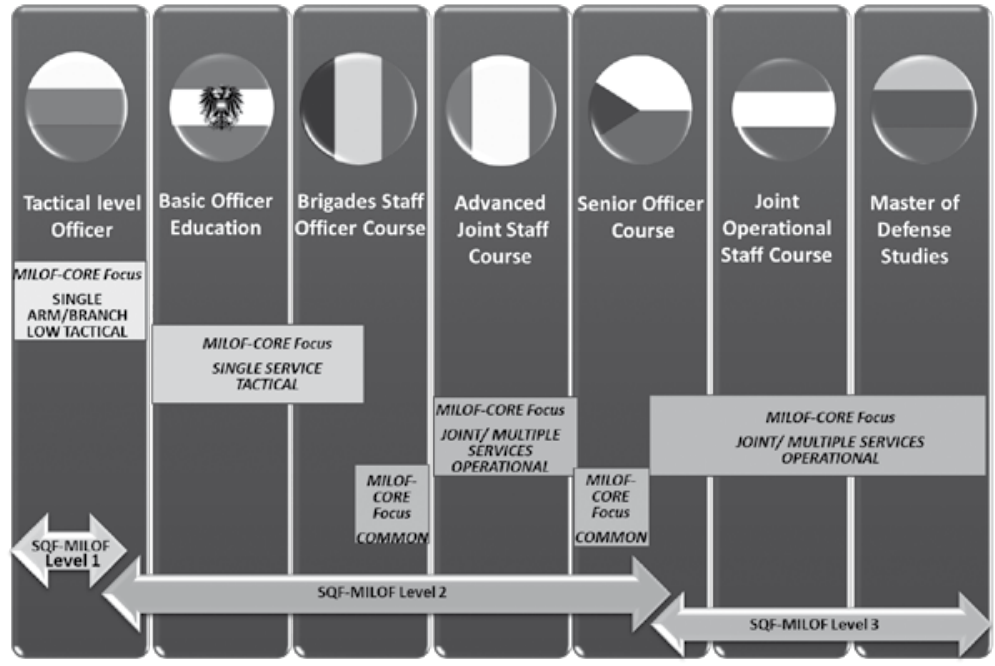

Picture 2: Comparison of levelling national military qualifications to the SQF-MILOF

Source: Based on "Levelling national military qualifications to SQF-MILOF and defining their military focus - Informal Validation Outcomes," European Security and Defence College, Brussels, ESDC/2021/051, 2021, ESDC Secretariat

The assessment regarding levelling national military qualifications to the SQF-MILOF mentioned above demonstrates that the SQF-MILOF is functional and useful tool that

11 EUROPEAN SECURITY AND DEFENCE COLLEGE. European Initiative for the Exchange of Young Officers: Comparison of courses based on competences (LoD 2). Brusel: ESDC, 2014, $8 \mathrm{~s}$. Available at: https://goo.gl/gYPaVr 
can be used by the national training providers. The main areas for the SQF-MILOF utilization can be seen in the domain of developing new curricula or refining and improving the existing ones by using the learning outcomes of the MILOF-CORE. Furthermore, there was proven a possibility to assign the SQF-MILOF level and a MILOF-CORE focus to the national military qualifications, thus facilitating the comparison among different similar qualifications granted by different Member States.

\section{NATIONAL VALIDATION OF THE SQF-MILOF}

In parallel with the process of levelling of the SQF-MILOF member states were consulted with regard to the utility, completeness of the SQF-MILOF and their intention to consider further implementation of the SQF-MILOF at national level. The national validation represented at this stage a non-binding acknowledgement by the EU members which do not necessitate to commit or implement it. In that survey 19 EU Member States took part and answered to the questionnaire ${ }^{12}$. From the perspective of this paper, it was essential how EU members see the content, form or value of the SQF-MILOF. One of the crucial question was, how well does the SQF-MILOF cover the needs of national military training and education system. The illustration of this answer is given in the Picture 3.

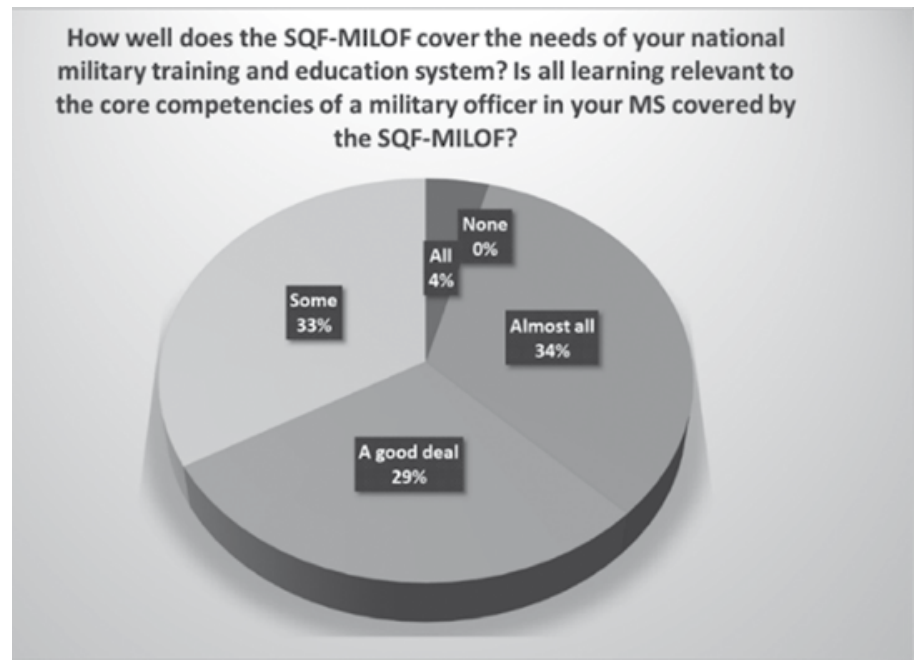

Picture 3: Pie chart of evaluation

Source: Sectoral Qualification Framework for the Military Officer Profession - Formal Validation Outcomes, European Security and Defence College, Brussels, ESDC/2021/050, 2021, ESDC Secretariat, page 4

12 Sectoral Qualification Framework for the Military Officer Profession - Formal Validation Outcomes, European Security and Defence College, Brussels, ESDC/2021/050, 2021, ESDC Secretariat. 
The majority of nations stated that the SQF-MILOF covers most of the core competencies of a military officer and thus it is relevant to the competencies of a military officer in that respect. However, some respondents stressed that there are service specific competencies to be only addressed by the service-oriented sectoral qualifications frameworks. Czech Republic confirmed that the SQF-MILOF covers a good deal of national military training and education system ${ }^{\mathbf{1 3}}$.

Respondents also generally verified that the content of the SQF-MILOF is clear and comprehensible by either its scope and its aim, or its structure. They all support that the main objectives of the SQF-MILOF, namely that it is a simplifying the comparison of the different national, military qualifications and thereby allowing the harmonization of the minimum (training) requirements for the military officers. A matter of value was perceived as very high by all the questioned entities and highlighted especially as an opportunity to contribute to the transparency of the military qualifications, promoting mobility and harmonization and improve interoperability. SQF-MILOF will increase the comparability of qualifications across the EU Member States as well as facilitate the exchange of military students and course participants at any stage of their military careers. Additionally, the SQF-MILOF has the capacity to promote and assist the national military qualification processes and the professional development of the military officers.

To conclude, it can be noticed that all respondents found the SQF-MILOF very useful representing a great opportunity to contribute to the transparency of the qualifications and help improve the interoperability of military officers across the European Union' armed forces.

\section{DISCUSSION}

It can be stated that results presented by other training providers concerning levelling their study programs to the SQF-MILOF correspond to some extent with the Czech findings in the fact that the EU framework generally covers their study programs and are relevant for required officer's competencies. But it needed to be stressed that the Czech approach to levelling was a little different in that respect, that all learning outcomes form the Czech career course program were selected for comparison (levelling) with the MILOF-CORE. This method enables to avoid the process of determination of key learning outcomes, which was mentioned by others as a problematic.

Based on the results of levelling the Czech study program to the SQF-MILOF there are a couple of factors needed to be taken into account. SQF-MILOF is generally based on the interpretation of the generic language of the EQF to the specific sector-oriented descriptors using military terminology. These are tailored for each of 8 competence areas in conjunction with the SQF-MILOF learning level articulating domains in the form of

13 Drawn from the official answers of the Czech Republic to the questionnaire "National validation of the Sectoral Qualifications Framework for the Military Officer Profession" to which author this article contributed. 
the knowledge, skills and responsibility \& autonomy. MILOF-CORE itself avoids those predefined domains as it is difficult to address and replicate them as such in teaching, learning and assessment (Table 1). On the contrary, the SOC contains descriptors divided strictly into areas of knowledge and skills but expressing a certain level of officer's career as MILOF-CORE does.

Senior officer course is based on the same principle as the SQF-MILOF as a general military education for all military occupation specialty. Nevertheless, the main differences to be found in the learning areas which are formulated with a different approach. In several cases, the SOC learning outcomes capture direct implications for the CAF. They contain some national specifics in the field of national defence planning, crisis management and national security architecture. The basic precondition for the Czech Republic is a collective defence according to Article 5 of the Washington Treaty. The planning domain relies especially on NATO defence planning (NDPP, NATO Defence Planning Process), including CAF capability development. Methods and principles applied in the field of crisis management are principally established on the NATO operations planning (COPD, Comprehensive Operations Planning Directive). Senior officer course should also ensure a certain degree of compatibility with NATO in the field of training (e.g. according to the study curriculum „Generic Officer Professional Military Education“).

Based on the findings of this paper, there are basically two ways in which the SQF-MILOF can be employed for the need of the Czech military carreer education. First approach can be found in the use of the Competence profile of the Military Officer defining a set of required competencies for classified competence areas based on the organizational level/ level of operations. It can be understood such as a competence model of armed forces. It might be supplemented by predefined learning areas in so called correspondence matrix, which shows the link between competencies and the learning. This methodology might create starting point to define relevant competencies for the CAF officers. Second approach built upon the results of levelling is the utilization of the MILOF-CORE, specifically its concrete learning outcomes descriptors for reviewing or update of existing study curricula.

Both above mentioned designs were partially adopted during recent revision of study programs of Senior Officer Course and General Staff Course organized by the CSMSS. Particularly, the Competence profile was applied for formulating general competencies for both senior officer and general staff course. Subsequently, the SQF-MILOF was employed especially for the purpose of detailed distinction between those carrier courses regarding organizational structure, i.e. level of operation where senior course is focused on the joint/multiple services at the operational level and general staff course is centered on political/civilian - military strategic level. Lessons learned drawn from the leveling were implemented during modification of the MILOF-CORE learning outcomes descriptors to both study programs. 


\section{CONCLUSION}

European Sectoral Qualifications Framework for Military Officer Profession was evaluated in this paper mainly from the perspective of its application in the Czech career education programs. From this point of view, it can be assumed that the main value of the SQF-MILOF rests in providing a comprehensive and broad taxonomy of descriptors of learning outcomes given by the MILOF-CORE. SQF-MILOF offers a comparative framework for the formulating of military qualifications, especially in terms of continuity between individual career courses or other study and educational programs provided within the Czech Ministry of Defence. MILOF-CORE itself delivers numerous relevant learning outcomes to support required officer's competencies.

As was stated in the Czech answers to the questionnaire the SQF-MILOF captures whole complexity of potential officer's operational engagement. It covers sufficiently all levels and categories of personnel across all services. Notwithstanding, it should be emphasized that national career courses should also ensure a degree of compatibility with NATO especially in the domain of defence planning and crisis management and they contain several national specifics. From this perception, it is crucial to take into account necessity to modify the SQF-MILOF, respectively the MILOF-CORE when they are applied to the national conditions. As it has been already mentioned experience and knowledge gained from levelling were employed in a recent revision of study programs of the Senior Officer Course and the General Staff Course organized by the CSMSS.

SQF-MILOF has not been evaluated from the perspective of mutual comparison of military qualifications among the EU Members States. In accordance with the opinion of the responsible body for military education within the State Secretary Division of the Czech Republic Ministry of Defence, the Czech Republic currently neither intends to sign an implementation protocol nor participates in a governance body. Nevertheless, the matter of signing a protocol could be potentially redeemed after the implementation of the SQF-MILOF across the EU nations. 
Author: Richard Saibert, Ph.D., born in 1969. He graduated from the Military University in Vyškov (1991). He held various command and staff positions in the Czech Armed Forces. Within the Ministry of Defence he also dealt with issues related to the defence policy of the Czech Republic. He has got also experience from foreign workplaces as well as from the civilian sector, especially in the area of project management and public procurement. He is currently working as a researcher at the Centre for Security and Military Strategic Studies, University of Defence. He publishes articles related to the military personnel development.

How to cite:SAIBERT Richard. European Sectoral Qualifications Framework for Military Officer Profession from the Perspective of the Czech Republic. Vojenské rozhledy. 2021, 30 (3), 059-074. ISSN 1210-3292 (print), 2336-2995 (online). Available at: www.vojenskerozhledy.cz 